Riga, Latvia, November 20, 2020

\title{
IMPLEMENTATION OF DIGITALIZATION OF LOGISTICS OUTSOURCING IN LINE AGENT BUSINESS PROCESSES
}

\author{
Irina Moskvichenko ${ }^{1}$ \\ Victoria Stadnik $^{2}$
}

DOI: https://doi.org/10.30525/978-9934-26-002-5-28

The current pace of globalization and the degree of competition in the container shipping market are forcing major players in the industry to look for new ways to organize business processes to make a profit in the limited conditions of a strict tariff policy. Leaders of the container shipping market, such as Maersk Line, CMA CGM, MSC are actively battling for turf and market share. Based on external conditions, taking into account low tariffs, insufficient demand and market oversaturation, we can conclude that further price reductions to increase market share and profit due to significant volumes at low margins are not just an ineffective strategy, but a direct threat to the company's survival. Therefore, the development of a new business process management strategy, particularly, the introduction of digitalization of logistics outsourcing, namely 5PL Supply Chain Management (Supply Chain Management, Virtual Logistics or Online Logistics) in the activity of line agent, which would occupy a unique niche and offer a convenient and high quality unique product, is one of the problematic issues in the container shipping industry.

Researchers as Nahorna O. V. [4], Kulyniak I. Ya. [5], Sharchuk T. V. [6] and Krasnoshapka V. V. [7] studied the area of application of outsourcing in the international practice and Ukraine.

Business processes performed by a line agent are especially important for the sea carrier, including retail - formation of the cargo base. The transfer of secondary tasks that need to be solved $24 / 7$ online will improve the quality of basic services.

Automation and cybersecurity are increasingly becoming key factors in outsourcing decisions. Globalism remains relevant in the outsourcing of information technology, business processes, and voice services. According to the data of GSLI (Global Services Location Index) 2019, India ranks first and Ukraine ranks 20th [5]. Therefore, it will be interesting and inappropriate to consider this issue clearly on the example of agent of Seago Line (Maersk Group) in Ukraine, who has developed and implemented a project to transfer the functions of a line agent to a global business service center in Mumbai, India.

${ }^{1}$ Odessa National Maritime University, Ukraine
${ }^{2}$ Odessa National Maritime University, Ukraine 
The general outsourcing project was developed at Seago Line A/S headquartered in Copenhagen, Denmark, and the project was implemented in phased manner in different regions. For the Black Sea region, which includes Turkey, Ukraine, Romania, Bulgaria and Georgia, the implementation has taken place during 2017-2018. In 2016, the project was successfully implemented for Great Britain.

All companies in A.P. Moller - Maersk A/S group mostly use customised software that allows you to process data, enter and receive the necessary information and generate reports globally. Among the global systems there are the following: CODS - Reports on equipment, ships, shipments; MDWS System of registration of instructions to the bill of lading; GCSS (Global Customer Service System) - Global system for work with shipments from the creation of booking to delivery of goods to the destination.

As a result of creating a service catalog and determining the possibility of transferring tasks to global business service center, the line agent Seago Line identified 93 tasks that can be outsourced, including 77 tasks related to exports and 16 tasks related to imports.

It is determined that the project's priority is the outsourcing of tasks related to exports. After determining the list of tasks that can be outsourced, a time analysis was performed by Seago Line's customer service staff was identified. As a result, the following data were obtained: tasks related to the support and registration of export shipments took $70 \%$ of working time; $27 \%$ of time was spent on tasks related to the support and registration of import shipments; $2 \%$ of time was devoted to tasks related to the provision of tariff rates; $1 \%$ of the time was occupied by other ancillary tasks.

Based on the data of the service catalog of line agent services, the share of time spent on 10 main tasks that can be outsourced to a global business service center was estimated.

In total, it is estimated that about $46 \%$ of the technical work related to export shipments performed by local agents will be outsourced. It is important to note that this amount of work includes making changes to the system and active communication with customers; therefore, some of these tasks may be transferred to local agents for communication and informing customers in Ukrainian. The project can be considered successful if 30\% of the technical workload is transferred to the Global Business Service Center, taking into account the need to eliminate overload and overwork from local agents.

Standard reporting functions on the Salesforce.com platform are used for determining the effectiveness of project implementation. This platform is used for correspondence from shared business e-mails. Salesforce.com allows you to generate reports on the number of cases resolved by certain agents. It should be noted that the reports are formed into a general case 
automatically, based on the bill of lading number specified in the subject of the message; therefore, the amount of letters and the amount of cases are not identical.

Table 1

Tasks selected for outsourcing

\begin{tabular}{|c|l|c|c|}
\hline & \multicolumn{1}{|c|}{ Task } & $\begin{array}{c}\text { Time, } \\
\text { seconds }\end{array}$ & $\begin{array}{c}\text { \% share of } \\
\text { observation } \\
\text { time }\end{array}$ \\
\hline 1 & Making changes or cancelling booking, GCSS & 8405 & 12.59 \\
\hline 2 & $\begin{array}{l}\text { Distribution and classification of messages } \\
\text { in a shared mailbox }\end{array}$ & 7255 & 10.86 \\
\hline 3 & Checking readiness of booking & 6353 & 9.51 \\
\hline 4 & Providing tariff rates & 2338 & 3.50 \\
\hline 5 & Entering the container information to booking & 1658 & 2.48 \\
\hline 6 & Issuance of original bills of lading on the WEB & 1650 & 2.47 \\
\hline 7 & Change of transportation plan & 1405 & 2.10 \\
\hline 8 & Confirmation of booking & 670 & 1.00 \\
\hline 9 & Sending messages related to the change of service & 653 & 0.98 \\
\hline 10 & Making changes to the draft bill of lading & 448 & 0.67 \\
\hline
\end{tabular}

The project allowed to normalize the workload of employees and give them more opportunities to maintain active interaction with key customers and expanded communication with those customers who have difficulties in organizing transportation via Seago Line.

Considering the digitalization of outsourcing as a possible tool for doing business and expanding operations, we can clearly conclude that it is successfully used in logistics. The decisive factor for the implementation of such a project is the versatility of systems and procedures used in different countries, as well as the technical and cognitive availability of information when using unified systems in virtual logistics or online logistics.

\section{References:}

1. Nahorna, O. V. (2013). Osoblyvosti vykorystannia autsorsynhu: mizhnarodnyi dosvid ta vitchyzniana praktyka [Features of outsourcing: international experience and domestic practice]. Krymskyi ekonomichnyi visnyk [Crimean economic Bulletin], vol. 2, pp. 29-32. Available at: http://ir.kneu.edu.ua:8080/handle/2010/3483 (accessed 10 November 2020).

2. Kulyniak, I. Ya., \& Hliantseva, O. I. (2014). Tendencii rozvytku svitovoho rynku autsorsynhu [Trends in the development of the global outsourcing market]. Naukovyi visnyk NLTU Ukrainy [Scientific Bulletin of NLTU of Ukraine], vol. 24.2. pp. 259-264. Available at: http://nbuv.gov.ua/UJRN/nvnltu_2014_24 (accessed 10 November 2020). 
3. Sharchuk, T. V. (2018). Lohistychnyi autsorsynh - shliakh do optymizatsii upravlinnia biznes-protsesamy pidpryiemstva [Logistics outsourcing - a way to optimize the management of business processes of the enterprise]. Bulletin of the National University «Lviv Polytechnic», no. 633, pp. 772-780.

4. Krasnoshapka, V. V., \& Trokhymets, I. I. (2015). Autsorsynh ta yoho zastosuvannia na pidpryiemstvakh Ukrainy [Outsourcing and its application at the enterprises of Ukraine]. Efektyvna ekonomika [Efficient economy] (electronic journal), no. 5. Available at: http://www.economy.nayka.com.ua/?op=1\&z=4097 (accessed 10 November 2020).

5. A.T. Kearney's 2019 Global Services Location Index (GSLI) Resonates with Digital Change. Website. Available at: https://www.prnewswire.com/news-releases/atkearneys-2019-global-services-location-index-gsli-resonates-with-digital-change300867002.html (accessed 10 November 2020).

\section{REGULATION OF THE BANKING SYSTEM OF AZERBAIJAN IN MODERN CONDITIONS}

\section{Mursalov Muslum ${ }^{1}$}

DOI: https://doi.org/10.30525/978-9934-26-002-5-29

The banking sector of Azerbaijan is one of the most important sectors of the national economy. Its functioning ensures the elimination of gaps in the movement of financial flows of business entities, the accumulation of capitalization of incomes of individuals and legal entities, and serves as the circulatory system of the state economy. The use of the powerful stimulating potential of this sector contributes to the equalization of the economic conditions of economic entities and ensures the financial stability of the country's economy. Against the background of the socio-economic crisis, the tasks of the state regulator in terms of reforming the banking sector are of particular importance. The latest trends in the socio-economic development of countries for a long time are associated with the intensification of external influences. In this context, it becomes necessary to form a new paradigm of state regulation of the banking sector in Azerbaijan, to develop forms and mechanisms of its influence on the socio-economic development of the state [1, p. 76-77; 2, p. 75-77].

1. In Azerbaijan, by the end of 2019, regulatory functions in the monetary system were divided between the Central Bank (hereinafter - CBAR) and the newly created regulatory body - the Chamber for Control over Financial

\footnotetext{
${ }^{1}$ Azerbaijan State University of Economics (UNEC), Azerbaijan
} 